\title{
Analisis Air, Substrat Tanah dan Cemaran Logam Berat Timbal (Pb) dan Cadmium (Cd) Pada Ikan Nila (Oreochromis Niloticus) Pada Waduk Tunggu Pampang Kelurahan Bitoa, Kota Makassar
}

\section{Analysis Of Water, Soil Substrate And Heavy Metal (Pb) And Cadmium (Cd) Metal In Nila Fish (Oreochromis Niloticus) In Waduk Tinggu Pampang Kelurahan Bitoa, Kota Makassar}

\author{
Selmi, Program Studi Pendidikan Teknologi Pertanian Fakultas Teknik, Universitas \\ Negeri Makassar. Email: Selmiantho@gmail.com \\ Wiharto, Program Studi Pendidikan Teknologi Pertanian Fakultas Teknik, Universitas \\ Negeri Makassar. Email: wiharto09@gmail.com \\ Patang, Program Studi Pendidikan Teknologi Pertanian Fakultas Teknik, Universitas \\ Negeri Makassar. Email: patang@unm.ac.id
}

\begin{abstract}
Abstrak
Waduk Tunggu Pampang merupakan salah satu waduk di kota Makassar yang dijadikan oleh beberapa kalangan masyarakat sebagai tempat menangkap ikan. Penelitian ini bertujuan untuk mengetahui kualitas air waduk, substrat tanah serta mengetahui ada tidaknya cemaran logam timbal $(\mathrm{Pb})$ dan cadmium $(\mathrm{Cd})$ pada ikan yang berasal dari waduk tunggu pampang. Metode penelitian adalah deskriptif kuantitatif. Pengujian air, tanah dan ikan dilakukan di BBIHP Makasaar dengan parameter amonia, nitrit, DO, Ph (tanah), komposisi tanah (pasir,debu,liat), $\mathrm{Pb}, \mathrm{Cd}$. Luas waduk tunggu pampang adalah 2,95 km. Hasil penelitian menunjukan kualitas air waduk tunggu pampang dalam kondisi yang baik jika dilihat dari parameter suhu,pH, DO, amonia, dan nitirit karena masih berada dikisaran baku mutu air menurut PP RI No. 82 tahun 2001 kelas III. Air,tanah dan ikan yang berasal dari waduk tunggu pampang telah mengandung cemaran logam berat $\mathrm{Pb}$ dan $\mathrm{Cd}$. Hasil penelitian air waduk menunjukan konsentrasi nilai logam berat $\mathrm{Pb}$ dan $\mathrm{Cd}$ sangat jauh di bawah ambang batas yang ditetapkan menurut PP RI No. 82 tahun 2001 sehingga masih dapat dimanfaatkan sesuai peruntukannya. Kandungan logam berat $\mathrm{Pb}$ dan $\mathrm{Cd}$ pada ikan nila masih jauh di bawah ambang batas yang ditetapkan berdasarkan SNI 2729:2013 untuk ikan segar. Jadi ikan yang diperoleh dari waduk tunggu pampang masih aman untuk dikonsumsi.
\end{abstract}

Kata Kunci : Kualitas Air,substrat tanah, waduk, Timbal, cadmium.

\section{Abstract}

The Tunggu Pampang Reservoir is one of the reservoirs in the city of Makassar that has been used by several communities as a place to catch fish. This study aims to determine the water quality of reservoirs, soil substrate and determine whether there is lead metal contamination $(\mathrm{Pb})$ and cadmium $(\mathrm{Cd})$ in fish originating from the pampang waiting reservoir. The research method is quantitative descriptive. Water, soil and fish tests were carried out in the Makasaar BBIHP with parameters such as ammonia, nitrite, DO, Ph (soil), soil composition (sand, dust, clay), $\mathrm{Pb}, \mathrm{Cd}$. The area of the tunggu pampang reservoir is $2.95 \mathrm{~km}$. The results showed that the water quality of the waiting reservoir was good in terms of the parameters of temperature, $\mathrm{pH}, \mathrm{DO}$, ammonia, and nitrite because it was still in the range of water quality standards according to PP RI No. 82 of 2001 class III. Water, soil and fish originating from the Tunggu pampang reservoir contain heavy metals $P b$ and $C d$. The results of the reservoir water research showed that the concentrations of $\mathrm{Pb}$ and Cd heavy metals were very far below the threshold set according to PP RI No. 82 of 2001 so that it can still be used 
according to its designation. The content of heavy metals $\mathrm{Pb}$ and $\mathrm{Cd}$ in tilapia is still far below the threshold set based on SNI 2729: 2013 for fresh fish. So fish obtained from Tunggu pampang reservoirs are still safe for consumption.

Keywords: Water Quality, soil substrate, reservoir, Lead, cadmium

\section{Latar Belakang}

Waduk Tunggu Pampang merupakan sebuah waduk yang yang berada di kelurahan Bitoa, Kecamatan Manggala Kota Makassar.waduk ini dibangun pada tahun 2001 oleh Pemerintah Kota Makassar.Pembangunan Waduk Tunggu Pampang dimaksudkan untuk mencegah terjadinya banjir akibat dari curah hujan yang tinggi serta drainase yang tidak berfungsi baik karena tumpukan sampah yang dibuang secara sembarangan olehmasyarakat sekitar. Meskipun pembangunan waduk telah selesai, namun tujuan awal perancanaan wakduk ini tidak tercapai secara maksimal karena banyak banyak hal yang menghambat. Salah satunya yakni pembebasan lahan masyarakat yang tidak pernah menemui kata sepakat (Prawitosarik, dkk.,2011).

Waduk Tunggu Pampang juga digunakan oleh masyarakat sebagai tempat untuk mencari dan menangkap ikan. Ikan yang biasanya ditangkap oleh masyarakat yaitu ikan nila jenis Gift (genetic improvement of farmed tilapias) yang ada dalam air waduk. Masyarakat memiliki berbagai cara atau alat untuk menangkap ikan nila, seperti menggunakan jaring, pukat, dan ada juga yang menggunakan pancing. Rata-rata ikan nila yang di tangkap berukuran $45 \mathrm{~mm}$ dan bahkan ada yang lebih besar.Biasanya hasil dari tangkapan masyarakat dijual langsung pada sekitar pinggir jalan daerah waduk dan ada juga yang dibawa pulang kerumah untuk dikonsumsi.

Namun belum diketahui secara pasti apakah ikan nila hasil tangkapan masyarakat tersebut tidak tercemar oleh berbagai bahan-bahan kimia yang sangat berbahaya pada tubuh seperti cemaran logam berat yang dicurigai terjadi secara alami dan juga berasal dari kendaraan bermotor yang lalu lalang pada sekitar waduk serta limbah rumah tangga yang masuk kedalam Waduk. Menurut Patang (2014), Kualiats air dapat Secara Luas didefinisikan sebagai fakor fisik, yang memepengaruhi penggunaan air kimia dan biologis untuk dimanfaatkan manusia baik secara langsung maupun tidak langsung.

Konsumsi ikan maupun produk olahan ikan yang tercemar logam berat berpotensi menimbulkan berbagai penyakit baik jangka pendek maupun jangka panjang.Kelainan syaraf, kelumpuhan, dan cacat bawaan pada bayi merupakan contoh penyakit-penyakit yang dapat ditimbulkan akibat kontaminasi logam berat (Dwiyitno, dkk., 2008). Hal inilah yang mendasari peneliti untuk melakukan penelitian pada ikan nila hasil tangkapan warga sekitar di waduk Tunggu Pampang untuk mengetahui seberapa besar kandungan cemaran logam berat timbal $(\mathrm{Pb})$ dan cadmium $(\mathrm{Cd})$ yang terdapat pada daging ikan nila tersebut.

\section{Tujuan Penelitian}

Penelitian yang dilakukan sesuai dengan rumusan masalah yang telah disebutkan bertujuan sebagai berikut :

1. Mengetahui kualitas air pada waduk Tunggu Pampang Kelurahan Bitoa, Kota Makassar.

2. Mengetahui substrat tanah pada waduk Tunggu Pampang Kelurahan Bitoa, Kota Makassar.

3. Mengetahui ada tidaknya cemaran logam berat pada ikan nila yang berasal dari waduk Tunggu Pampang Kelurahan Bitoa, Kota Makassar. 


\section{Bahan dan Metode}

\section{Jenis Penelitian}

Jenis penelitian adalah jenis penelitian kuantitatif dengan menggunakan pendekatan deskriptif. Dalam penelitian ini digunakan untuk menggambarkan cemaran logam berat pada ikan nila yang berasal dari waduk tunggu pampang, berdasarkan observasi ke lapangan dan pemeriksaan di laboratorium.

\section{Tempat}

Analisis Suhu dan $\mathrm{pH}$ air dilakukan langsung di Waduk Tunggu Pampang sedangkan analisis cemaran logam air, tanah dan ikan nila, amonia, nitrit dari waduk tunggu pampang kelurahan Bitoa, kota Makassar dilakukan di Balai Besar Industri Hasil Perkebunan (BBIHP).

\section{Waktu}

waktu penelitian mulai dari persiapan, analisis cemaran logam berat membutuhkan waktu selama 3 bulan terhitung sejak bulan April 2018. Pengambilan sampel dilakukan selama satu minggu mulai tanggal 20-27 Mei 2018.

\section{Teknik Pengumpulan Data}

Pengumpulan data yang digunakan dalam penelitian ini secara garis besar ada dua jenis data yaitu data primer dan data sekunder.Data primer adalah data yang hanya dapat kita peroleh dari sumber asli atau pertama sedangkan data sekunder merupakan data yang sudah tersedia sehingga kita tinggal mencari dan mengumpulkan.Data sekunder dalam penelitian ini berupa pustaka-pustaka terkait penelitian, lembaga penelitian, dinas perikanan, maupun masyarakat yang berhubungan langsung dengan penelitian ini.

\section{Analisis Kualitas Air}

a. Derajat keasamaan $(\mathrm{pH})$ air Waduk diukur langsung di lokasi penelitian menggunakan $\mathrm{pH}$ meter. Pengukuran dilakukan pagi hari pada pukul 07.00
WITA dan sore hari pada pukul 17.00 WITA setiap 1 minggu sekali selama 1 bulan.

b. Suhu diukur langsung pada lokasi penelitian menggunakan thermometer batang. Pengukuran dilakukan pagi hari pada pukul 07.00 WITA pada sore hari pada pukul 17.00 WITA setiap 1 minggu sekali selama 1 bulan.

c. Oksigen terlarut atau DO (Disolved Oxygen) Metode ini meliputi cara uji kadar oksigen terlarut (Dissolved Oxygen, DO) dari contoh air.

\section{Substrat Tanah}

Cara pengambilannya yaitu dengan menggunakan pipa paralon dengan diameter $56 \mathrm{~mm}$, panjang pipa yang digunakan 2 meter.Pipa paralon ditancapkan pada dasar waduk kemudian diangkat kembali untuk mendapatkan jenis tanah dalam waduk ini pada tiga stasiun yang berbedah yakni stasiun 1, stasiun 2, dan stasiun 3 pada waduk tersebut. Setelah diambil, tanah yang digunakan sebagai sampel untuk mengetahui tingkat cemarannya pada ikan nila maka dilakukanlah pengamatan terhadap tanah tersebut dengan cara dianalisis di laboratorium dengan menggunakan peralatan yang sesuai untuk meneliti objek, guna memperoleh hasil yang ingin diketahui yakni kandungan atau tingkat cemaran pada tanah tersebut.

\section{Ikan Nila}

Dalam penelitian ini difokuskan pada ikan nila ukuran $45 \mathrm{~mm}$ yang sering ditangkap oleh nelayan sekitar waduk jenis Gift (genetic improvement of farmed tilapias) yang menjadi objek penelitian untuk memperoleh data terkait tentang tingkat cemaran logam berat Timbal $(\mathrm{Pb})$ dan cadmium $(\mathrm{Cd})$ terhadap daging ikan tersebut. Adapun cara memperoleh atau mengambil ikan tersebut yang ada dalam waduk tunggu pampang, yakni dengan cara dijala.

Pengelolahan ikan nila dimulai dengan dicuci, disisik kulitnya, dipisahkan 
bagian dalam ikan. Ikan yang sudah dikuliti dan diambil dagingnya selanjutnya diteliti dengan perlakuan penelitian yang diterapkan adalah analisis kadar logam berat timbal $(\mathrm{Pb})$ dan cadmium $(\mathrm{Cd})$ yang terkandung dalam daging ikan nila. Sampel yang digunakan adalah daging ikan nila yang dihaluskan menjadi partikel kecil dengan alat penggiling (blender) dan ditimbang berat basahnya 25 gram.lalu dikeringkan dengan cara di oven pada suhu 1000C selama 18 jam, setelah kering lalu ditimbang. Selanjutnya dilakukan destruksi dengan menggunakan $\mathrm{HNO} 3$ pekat dan $\mathrm{H} 2 \mathrm{O} 2$ masing-masing sebanyak $10 \mathrm{ml}$ dan $5 \mathrm{ml}$ sampai sampel daging ikan nila kering larut dalam larutan asam yang ditambahkan, proses ini dilakukan di Balai Besar Industri Hasil Perkebunan (BBIHP) Kota Makassar.

\section{Teknik Analisis Data}

Analisis yang digunakan adalah analisis deskriptif dengan memaparkan hasil penelitian cemaran logam berat pada ikan nila menggunakan program Microsoft excel 2013 dalam penyajian historgram atau diagram batang dan hasil analisis residu logam berat pada ikan disajikan dalam bentuk tabel. Data hasil Analisis residu logam berat dibandingkan dengan batas maksimum cemaran logam berat yang terdapat dalam bahan pangan ikan segar berdasarkan SNI 2729:2013.

\section{Hasil dan Pembahasan}

\section{Kualitas Air Waduk Tunggu Pampang}

\section{pH Air}

Data rata-rata hasil penelitian menunjukan nilai $\mathrm{pH}$ pada stasiun 1 sebesar 8.5, stasiun 2 sebesar 8.3, dan stasiun 3 sebesar 8.3. Nilai $\mathrm{pH}$ ini masih tergolong cukup baik karena berada dikisaran standar mutu yang telah ditetapkan yaitu berada dalam kisaran nilai $\mathrm{pH}$ antara 6-9 berdasarkan standar mutu kualitas air kelas III menurut PP RI No. 82 tahun 2001 yang merupakan standar nilai $\mathrm{pH}$ yang dapat pembudidayaan ikan air tawar, peternakan, air untuk mengairi pertanaman, dan atau peruntukan lain yang mempersyaratkan air yang sama dengan kegunaan tersebut (lampiran 9).

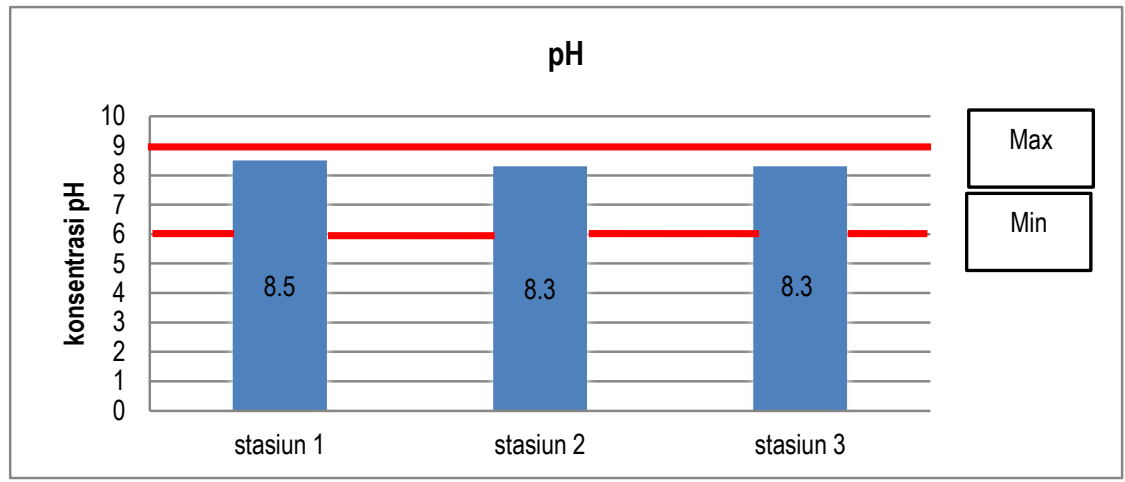

Gambar 1.Histogram nilai pH Air Waduk Tunggu Pampang

\section{Suhu Air}

Berdasarkan hasil pengukuran suhu perairan Waduk Tunggu Pampang pada masing-masing stasiun pengamatan menunjukan bahwa tidak terjadi perbedaan yang besar atau relatif stabil yang berkisar antara 25 - 270C. Jika dibandingkan dengan standar baku mutu air kelas III berdasarkan PP RI No. 82 tahun 2001 (lampiran 9) dari keadaan alamiah, maka kondisi kualitas air sungai ditinjau dari parameter suhu masih dalam batas baku mutu air sesuai peruntukannya. Menurut Asrini (2017), suhu berperan mengendalikan kondisi ekosistem perairan. Suhu air Waduk Tunggu Pampang masih dapat mendukung dalam hal pertumbuhan fitoplankton. Adanya perbedaan suhu pada masing-masing stasiun disebabkan oleh intensitas cahaya yang diterima oleh masing-masing stasiun. 


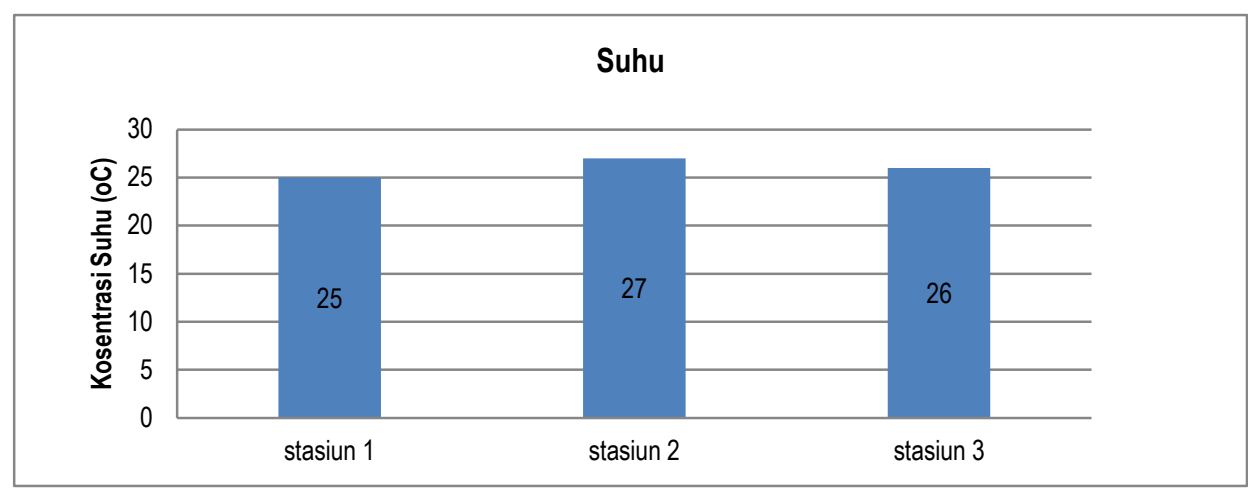

Gambar 2. Histogram nilai Suhu Air Waduk Tunggu Pampang

\section{Dissolved Oxygen (DO)}

Hasil pengukuran oksigen terlarut (DO) air Waduk Tunggu Pampang pada pengambilan sampel di tiga titik stasiun sudah jauh melewati nilai ambang minimum konsentrasi nilai DO dalam kriteria mutu air kelas III (PP RI No. 82 Tahun 2001) yaitu minimum $3 \mathrm{mg} / \mathrm{L}$, sehingga air Waduk dengan nilai parameter DO berkisar 5 - 6 masih baik digunakan untuk peternakan dan pertanian serta peruntukan lainnya.

Suatu perairan dapat dikatakan baik jika tingkat pencemaran yang rendah dengan kadar oksigen terlarutnya (DO) lebih besar dari $5 \mathrm{mg} / \mathrm{L}$ (Mahyudin dkk., 2015).Jika dibandingkan dengan hasil pengukuran nilai oksigen terlarut pada waduk tunggu pampang yang memiliki nilai DO $5-6 \mathrm{mg} / \mathrm{L}$ masih tergolong perairan yang baik dan rendah tingkat pencemarannya.

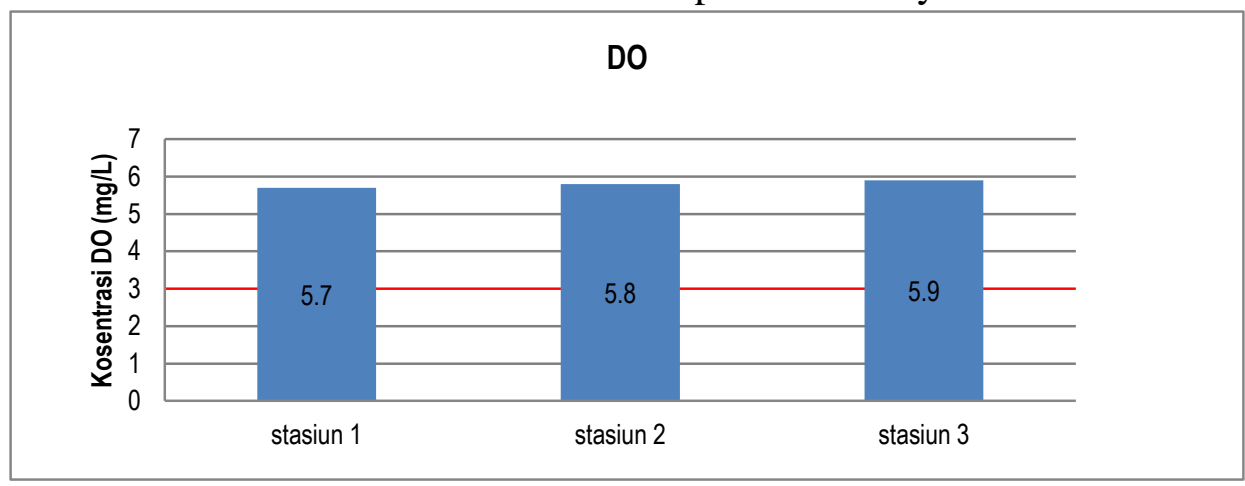

Gambar 3. Histogram nilai DO Air Waduk Tunggu Pampang

\section{Amonia}

Hasil penelitian amonia yang dilakukan di tiga titik stasiun pada Waduk Tunggu Pampang, menggambarkan bahwa kadar amonia yang ada dalam perairan Waduk Tuggu Pampang masih dalam jumlah sedikit dan jauh dari ambang batas yang telah ditentukan namun perlu pengawasan dari pemerintah setempat.

Menurut Mia dan Mira (2015) amonia dapat bersifat racun pada manusia jika jumlah yang masuk ke dalam tubuh melebihi jumlah yang dapat didetoksifikasi oleh tubuh yakni tidak lebih dari $100 \mathrm{mg} / \mathrm{kg}$ setiap hari $(33,7 \mathrm{mg}$ ion amonium per $\mathrm{kg}$ berat badan per hari) yang dapat mempengaruhi metabolisme dengan mengubah kesetimbangan asam-basa dalam tubuh. Amonia yang ada yang ada pada perairan Waduk Tunggu Pampang diperkirakan berasal dari limbah pupuk pertanian seperti urea yang adadi sekitar lokasi Waduk serta hasil dari metabolisme pada ikan yaitu urin dan kotorannya. 
Tabel 1.nilai Amonia Air Waduk Tunggu Pampang

\begin{tabular}{cc}
\hline Stasiun sampel & Hasil $(\mathbf{m g} / \mathbf{L})$ \\
\hline $\mathbf{1}$ & 0,2822 \\
$\mathbf{2}$ & 0,3288 \\
$\mathbf{3}$ & 0,4127 \\
Ambang Batas & 0,800 \\
\hline
\end{tabular}

Sumber : Balai Besar Industri Hasil Perkebunan

\section{Nitrit}

Dari hasil penelitian nitrit yang telah dilakukan di tiga stasiun pada Waduk Tunggu Pampang memiliki kadar tidak jauh berbeda pada tiap stasiun yaitu sebesar 0.006-0.0021 $\mathrm{mg} / \mathrm{L}$. Dari hasil tersebut dapat kita simpulkan bahwa kadar nitrit yang ada dalam perairan waduk tuggu pampang masih dalam jumlah sedikit dan jauh dari ambang batas yang telah ditentukan yaitu sebesar 0,06 $\mathrm{mg} / \mathrm{L}$ berdasarkan PP RI No. 82 tahun 2001 (lampiran 9). Akan tetapi, keberadaan nitrit dalam perairan Wduk Tunggu Pampang perlu pengawasan dari pemerintah setempat Berdasarkan hasil pengamatan, nitrit yang ada pada perairan Waduk Tunggu Pampang berasal dari limbah rumah tangga yang keluar dari kawasan padat pemukiman tentunya berpengaruh terhadap tingginya kandungan nitrit pada waduk. Hal tersebut sesuai dengan pendapat Aswadi (2006) yang mengatakan peningkatan beban cemaran nitrit dipengaruhi terutama antara lain oleh sistem saluran pembuangan dimana limbah buangan rumah tangga akan menambah konsentrasi nitrit.

Tabel 2. Nilai Nitrit Air Waduk Tunggu Pampang

\begin{tabular}{cc}
\hline Stasiun sampel & Hasil $(\mathbf{m g} / \mathbf{L})$ \\
\hline $\mathbf{1}$ & 0,0316 \\
$\mathbf{2}$ & 0,0397 \\
\hline $\mathbf{3}$ & 0,0337 \\
\hline Ambang Batas & 0,0600 \\
\hline
\end{tabular}

Sumber : Balai Besar Industri Hasil Perkebunan

\section{Substrat Tanah Waduk Tunggu Pampang pH Tanah}

Hasil pengukuran $\mathrm{pH}$ tanah pada Waduk bekisar 6.42-7.24. Selisih nilai $\mathrm{pH}$ masing-masing stasiun sebesar 0.19-0,82 dapat diindikasikan bahwa nilai $\mathrm{pH}$ pada perairan waduk ini hampir sama pada ketiga stasiun Devy (2017) dalam jurnalnya menyatakan bahwa Pusat Penelitian Tanah dari Departemen Pertanian (1983) telah mengajukan kriteria penilaian sifat kimia tanah berdasarkan sifat umum tanah yang didapat secara empiris. Nilai $\mathrm{pH}$ tanah yang baik berdasakan pernyataan tersebut adalah 7,5 (netral) dan jika dibandingkan dengan hasil penlitian $\mathrm{pH}$ tanah pada Waduk Tunggu Pampang, maka dapat disimpulkan bahwa nilai $\mathrm{pH}$ tanah Waduk masih tergolong baik meskipun hampir bersifat agak asam. 


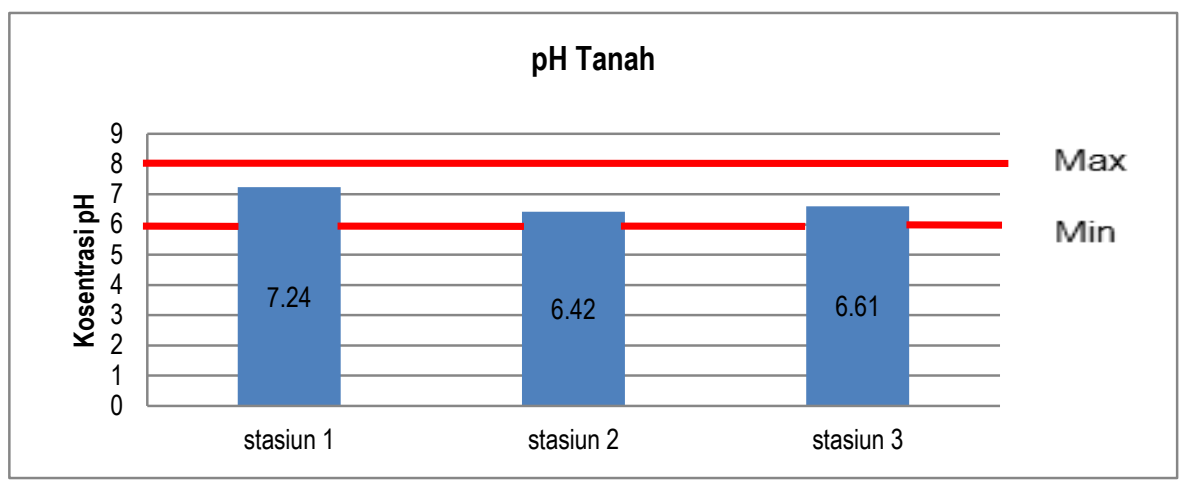

Gambar 4. Histogram nilai pH Tanah Waduk Tunggu Pampang

\section{Tekstur Tanah}

Dari hasil penelitian yang telah dilakukan pada tiga stasiun di Waduk Tunggu Pampang menunjukkan bahwa komposisi (pasir,debu,liat) tanah setiap stasiun berbeda. Pada stasiun 1 kandungan yang paling besar adalah liat sebesar $53.86 \%$ lebih banyak dari kandungan pasir dan debu. Berbeda pada stasiun 2 kandungan yang paling besar adalah pasir sebesar $43.76 \%$ lebih banyak dari pada liat dan debu. Pada stasiun 3 kandungan tanah yang paling besar kembali didominasi oleh liat sebesar $41.60 \%$ lebih besar dari pada pasir dan debu.Dari data hasil besaran persentase kandungan tanah pada masingmasing stasiun dapat di simpulkan bahwa tanah yang ada pada Waduk Tunggu Pampang adalah liat

Tabel 3.Nilai Komposisi Tanah Waduk Tunggu Pampang

\begin{tabular}{ccccc}
\hline \multirow{2}{*}{ No } & \multirow{2}{*}{ Nama Stasiun } & \multicolumn{3}{c}{ Jenis Tanah (\%) } \\
\cline { 3 - 5 } & & Pasir & Debu & Liat \\
$\mathbf{1}$ & 1 & 14,79 & 31,35 & 53,86 \\
$\mathbf{2}$ & 2 & 43,76 & 17.08 & 39,15 \\
$\mathbf{3}$ & 3 & 25,83 & 32,51 & 41,66 \\
\hline
\end{tabular}

Sumber : Balai Besar Industri Hasil Perkebunan

\section{Cemaran Logam Berat}

\section{Logam Berat Pada Air}

Hasil penelitian kadar timbal $(\mathrm{Pb})$ pada air Waduk masih jauh dibawah batas maksimum konsentrasi logam berat timbal $(\mathrm{Pb})$ berdasarkan kriteria mutu air kelas III (PP RI No. 82 Tahun 2001) yaitu maksimum kadar $\mathrm{Pb}$ sebesar $0,03 \mathrm{mg} / \mathrm{L}$. Jadi air Waduk Tunggu Pampang masih cukup aman dimanfaatkan sesuai peruntukan yang mengisyaratkan penggunaan air kelas III (PP RI No. 82 Tahun 2001). Menurut Palar (2012) timbal $(\mathrm{Pb})$ yang masuk ke dalam perairan berasal dari aktivitas kehidupan manusia diantaranya air buangan limbah industri seperti pertambangan bijih timah, sisa industri baterai, buangan gas kendaraan bermotor dan pembakaran batu bara. Aktivitas masyarakat sehari-hari dapat menyebabkan masuknya bahan pencemar (Alfia, dkk.,2019).

Hasil penelitian kadar cadmium $(\mathrm{Cd})$ pada air waduk masih jauh dibawah batas maksimum konsentrasi logam berat cadmium (Cd) berdasarkan kriteria mutu air kelas III (PP RI No. 82 Tahun 2001) yaitu maksimum kadar Cd sebesar 0,01 $\mathrm{mg} / \mathrm{L}$ sedangkan nilai kadar Cd pada waduk sebesar 0,003 mg/L. Jadi air Waduk Tunggu Pampang masih cukup aman digunakan atau dimanfaatkan sesuai kebutuhan seperti untuk penyiraman tanaman yang ada disekitar waduk dengan memanfaatkan air waduk. Logam berat 
mempunyai sifat yang mudah mengikat bahan organik dan mengendap didasar perairan dan bersatu dengan sedimen (Rolinsa, 2014)

Tabel 4.Nilai Logam Berat Air Waduk Tunggu Pampang

\begin{tabular}{ccc}
\hline Titik sampel & \multicolumn{2}{c}{ Parameter Logam Berat } \\
\cline { 2 - 3 } & $\mathbf{P b}(\mathbf{m g} / \mathbf{L})$ & $\mathbf{C d}(\mathbf{m g} / \mathbf{L})$ \\
\hline Stasiun 1 & 0.002 & 0.003 \\
\hline Stasiun 2 & 0.002 & 0.003 \\
\hline Stasiun 3 & 0.002 & 0.003 \\
\hline Ambang batas $\left.^{*}\right)$ & 0.03 & 0.01 \\
\hline
\end{tabular}

Sumber : Balai Besar Industri Hasil Perkebunan

\section{Logam Berat Pada Tanah}

Hasil penelitian logam berat timbal $(\mathrm{Pb})$ pada ketiga stasiun pengambilan sampel sangat tinggi jika dibandingkan dengan ambang batas yang telah ditentukan oleh Badan Standarisasi Nasional-SNI, 2004 yaitu

sebesar $0.07 \mathrm{mg} / \mathrm{kg}$. Dengan demikian dapat disimpulkan bahwa Timbal yang ada dalam tanah pada waduk tunggu pampang sudah berbahaya dan sebagian telah terakumulasi dalam ikan.
Hasi penelitian cemaran logam berat Cadmium (Cd) yang telah dilakukan pada tiga stasiun di waduk tunggu pampang menunjukkan angka $0.01 \mathrm{mg} / \mathrm{kg}$ yang dapat diindikasikan bahwa kondisi tanah pada lokasi penelitian belum tercemar kadmium pada batas yang membahayakan yang telah ditentukan oleh Badan Standarisasi Nasional-SNI, 2004 yaitu sebesar 0.1 $\mathrm{mg} / \mathrm{kg}$.

Tabel 5. Nilai Logam Berat Tanah Waduk Tunggu Pampang

\begin{tabular}{ccc}
\hline \multirow{2}{*}{ Titik sampel } & \multicolumn{2}{c}{ Parameter Logam Berat } \\
\cline { 2 - 3 } & $\mathbf{P b}(\mathbf{m g} / \mathbf{k g})$ & $\mathbf{C d}(\mathbf{m g} / \mathbf{k g})$ \\
\hline Stasiun 1 & 11.90 & 0.1 \\
\hline Stasiun 2 & 13.00 & 0.1 \\
\hline Stasiun 3 & 40.06 & 0.1 \\
\hline Ambang batas ${ }^{*}$ & 0.07 & 0.01 \\
\hline
\end{tabular}

Sumber : Balai Besar Industri Hasil Perkebunan

\section{Logam Berat Ikan}

Hasil penelitian uji kadar timbal $(\mathrm{Pb})$ yang terdapat dalam ikan cukup tinggi yaitu sebesar $0,10 \mathrm{mg} / \mathrm{kg}$. Hal ini terjadi diperkirakan karena ukuran dari tubuh ikan nila lebih besar sehingga nilai kadar konsentrasi logam timbal $(\mathrm{Pb})$ dalam tubuh ikan nila juga tinggi. Kembali mengacu pada penelitian Atira Dkk (2014) yang menyatakan semakin besar ukuran tubuh ikan maka ukuran makanan yang dimakan juga akan semakin besar. Akan tetapi kandungan timbal $(\mathrm{Pb})$ yang terdapat pada ikan nila masih jauh dibawah ambang batas maksimum logam berat yang terdapat dalam ikan segar berdasarkan SNI 2729:2013 dengan ambang batas maksimum logam $\mathrm{Pb}$ yang dibolehkan sebesar 0,3 $\mathrm{mg} / \mathrm{kg}$. Menurut Manna dkk.,(2017) semua logam berat dapat menjadi bahan racun yang meracuni makhluk hidup. 
Adanya cemaran logam berat timbal $(\mathrm{Pb})$ yang terdapat di Waduk Tunggu Pampang kemungkinan besar berasal dari udara akibat buangan gas kendaraan bermotor dengan jumlah yang besar (karena berada di dalam perkotaan) dengan membentuk pengkristalan dengan bantuan air hujan dan dibawah ke perairan waduk melalui saluran air sehingga air waduk terkontaminasi logam berat timbal $(\mathrm{Pb})$. Menurut Palar (2012) bahwa Pb yang ada dalam udara terutama bersumber dari buangan (asap) kendaraan bermotor yang sebagian membentuk partikulat-partikulat di udara bebas dan sebagian menempel dan diserap oleh daun tumbuh-tumbuhan.

Hasil penelitian menunjukan kadar cadmium $(\mathrm{Cd})$ pada ikan nila sama dengan kandungan logam berat timbal $(\mathrm{Pb})$ yaitu sebesar 0,10 mg/kg. Kadar cadmium (Cd) yang terdapat dalam ikan lebih tinggi jika dibandingkan dengan kadar cadmium (Cd) pada air waduk yaitu kurang dari 0,003 $\mathrm{mg} / \mathrm{L}$. Hal ini terjadi akibat dari sifat logam yang apabila masuk kedalam tubuh biota akan membentuk senyawa-senyawa kompleks dengan zat-zat organik yang terdapat dalam sel-sel tubuh biota akuatik. Akan tetapi kandungan cadmium (Cd) yang terdapat pada ikan masih jauh dibawah ambang batas maksimum logam berat yang terdapat dalam ikan segar berdasarkan SNI 2729:2013 dengan ambang batas maksimum logam $\mathrm{Cd}$ yang dibolehkan sebesar $0,1 \mathrm{mg} / \mathrm{kg}$.

Penyebab dari lebih tingginya kandungan kadar cadmium (Cd) yang terdapat dalam ikan nila sebesar $0,10 \mathrm{mg} / \mathrm{kg}$ diperkirakan juga karena ukuran ikan nila saat pengambilan sampel ikan sehingga jumlah kadar logam berat cadmium (Cd) lebih banyak terserap oleh tubuh ikan nila.

Tabel 6. Nilai Logam Berat Ikan Waduk Tunggu Pampang Titik sampel Parameter Logam Berat

\begin{tabular}{ccc}
\cline { 2 - 3 } & $\mathbf{P b}(\mathbf{m g} / \mathbf{k g})$ & $\mathbf{C d}(\mathbf{m g} / \mathbf{k g})$ \\
\hline Stasiun 1 & 0.1 & 0.1 \\
\hline Stasiun 2 & 0.1 & 0.1 \\
\hline Stasiun 3 & 0.1 & 0.1 \\
\hline Ambang batas $\left.^{*}\right)$ & 0.3 & 0.1 \\
\hline
\end{tabular}

Sumber : Balai Besar Industri Hasil Perkebunan

\section{Simpulan}

Berdasarkan hasil penelitian Analisis Air, Substrat Tanah Dan Cemaran Logam Berat Timbal $(\mathrm{Pb})$ Dan Cadmium $(\mathrm{Cd})$ Pada Ikan Nila (Oreochromis Niloticus) Pada Waduk Tunggu Pampang Kelurahan Bitoa, Kota Makassar, maka diperoleh kesimpulan yaitu Kualitas air waduk tunggu pampang dalam kondisi yang baik jika dilihat dari parameter suhu, $\mathrm{pH}, \mathrm{DO}$, amonia, nitrit karena masih berada dikisaran baku mutu air yang ditetapkan serta air waduk tunggu pampang telah mengandung cemaran logam berat $\mathrm{Pb}$ dan $\mathrm{Cd}$ tetapi nilai kandungan logam berat pada air waduk sangat jauh di bawah ambang batas yang ditetapkan menurut PP RI No. 82 Tahun 2001 yaitu untuk konsentrasi $\mathrm{Pb}$ maksimum $0,03 \mathrm{mg} / \mathrm{L}$ sedangkan pada air waduk di tiga stasiun diperoleh kandungan $\mathrm{Pb}$ sebesar 0,002 mg/L. Untuk konsentrasi $\mathrm{Cd}$ maksimum yang ditetapkan $0,01 \mathrm{mg} / \mathrm{L}$ sedangkan pada air waduk di tiga stasiun diperoleh kandungan $\mathrm{Cd}$ sebesar 0,003 $\mathrm{mg} / \mathrm{L}$. Sehingga air waduk masih sesuai untuk peruntukan yang mengisyaratkan air dalam hubungannya dengan aktivitas perikanan.

Substat tanah yang ada dalam kondisi yang baik jika dilihat dari parameter $\mathrm{pH}$. Jenis tanah pada waduk jika dilihat dari 3 stasiun pengambilan sampel adalah jenis 
tanah liat. Waduk tunggu pampang telah mengandung cemaran logam berat Timbal $(\mathrm{Pb})$ yaitu pada stasiun 1 sebesar 11.90 $\mathrm{mg} / \mathrm{kg}$, stasiun 2 sebesar $13.00 \mathrm{mg} / \mathrm{kg}$, stasiun 3 sebesar $40.06 \mathrm{mg} / \mathrm{kg}$. Kandungan logam berat Timbal $(\mathrm{Pb})$ pada tanah sudah melewati ambang batas yang telah ditentukan oleh Badan Standarisasi Nasional-SNI,2004 yaitu sebesar 0.07 $\mathrm{mg} / \mathrm{kg}$. Untuk konsentrasi Cadmium (Cd) pada tanah WADUK di tiga stasiun diperoleh kandungan Cadmiun (Cd) sebesar 0,1 mg/kg. Kandungan logam berat Cadmium (Cd) pada tanah sudah melewati ambang batas yang telah ditentukan oleh Badan Standarisasi Nasional-SNI,2004 yaitu sebesar $0.01 \mathrm{mg} / \mathrm{kg}$.

Hasil penelitian menunjukan pada ikan nila yang berasal dari waduk tunggu pampang telah mengandung cemaran logam berat Timbal (Pd) dan Cadmium (Cd). Namun demikian kandungan logam berat pada ikan nila masih di bawah ambang batas yang ditetapkan berdasarkan SNI 2729:2013 untuk ikan segar. Jadi ikan yang diperoleh dari waduk tunggu pampang masih aman untuk dikonsumsi tetapi jika dikonsumsi secara terus menerus diperkirakan akan berdampak buruk bagi kesehatan dalam jangka panjang.

\section{Daftar Pustaka}

Alfia, A., A., N., Patang dan Ernawati S.,K. 2019. Pengaruh Eutrofikasi Terhadap Kualitas Air di sungai Jeneberang. Jurnal. Pendidikan Teknoligi Pertanian. Vol 5. : 9-23.

Asrini N., K.2017. Studi Analisis Kualitas Air di Daerah Aliran Sungai Pakerisan Profinsi Bali. Jurnal. Dinas Kesehatan Kabupaten Klungkung. Fakultas Pertanian: Unuversitas Undayana.

Aswadi, M. 2006, Pemodelan Fluktuasi Nitrogen (Nitrit) Pada Aliran Sungai Palu. Jurnal SMARTek, Vol. 4 No.2 Mei. 2006.

Atira D., Ridwan M. P., dan Deni E. 2014. Analisis Perut Trichogaster pectoralis. Skripsi. Riau : Fakultas Ilmu Kelautan dan Perikanan Uneversitas Riau.

Devy L. 2017. Baku Mutu Tanah. Skripsi. Jurusan Perikanan Dan Kelautan. Universitas Negeri Semarang.

Dwiyitno., Nugroho A., dan Ninoek I. 2008. Residu Logam Berat pada Ikan dan Kualitas Lingkungan Perairan Muara Sungai Barito Kalimantan Selatan. Jurnal Pascapanen dan Bioteknologi Kelautan dan Perikanan Vol. 3 No. 2.

Mahyudin dan Soemarno. 2015. Analisis Kualitas Air dan Strategi Pengendalian Pencemaran Air Sungai Metro di Kota Kepanjen Kabupaten Malang. J-PAL, Vol. 6, No. 2.

Mia A., dan Mira H. 2015. Analisis Kadar Amonia (NH3) Dalam Air Sungai Cileungsi. Skripsi. Program studi biologi FMIPA.Universitas Nusa Bangsa Bogor.

Palar, Heryando. 2012. Pencemaran dan Toksikologi Logam Berat. Penerbit Rineka Cipta : Jakarta.

Prawitosari, T., Idris., dan Ismail. 2011. Evaluasi Kapasitas Tampung Waduk Tunggu Pampang Kota Makassar. Skripsi. Fakultas Pertanian : Universitas Hasanuddin.

Patang. 2014. Use of antibiotic and probiotic controlling water quality, growth and survival of shrimp larvae penaeus monodon fabricus. Asian Jr.Of Microbiol.Biotech.Env. Sc. Vol. 16, No. (2) : 2014 : 241 245.

Rolinsa R., D. 2014. Uji Kadar Merkuri Pada Beberapa Jenis Ikan Diperairan Laut Sulawesi. Tesis. Gorontalo: Program Studi Kesehatan Masyarakat Peminatan Kesehatan Lingkungan Fakultas Ilmu-Ilmu Kesehatan Dan Keolagragaan Universitas Negeri Gorontalo. 
Wanna, M., S. Yanto, dan Kadirman. 2017. Analisis Kualitas Air dan Cemaran Logam berat Merkuri (Hg) dan Timbal $(\mathrm{Pb})$ pada Ikan di Kanal Daerah Hertasning Kota Makassar. Jurnal. Pendidkan Teknologi Pertanian. Vol.3. September Suplemen : S197-210. 